\title{
The effect of temperature and genotype on growth traits, plasma glucose and uric acid in Dwarf and Normal White Leghorn females
}

\author{
A.K. BANERJEE (*), A. BORDAS et P. MERAT \\ I.N.R.A., Laboratoire de Génétique factorielle \\ Centre de Recherches zootechniques \\ F 78350 Jouy-en-Josas
}

\begin{abstract}
Summary
Day old White Leghorn female chicks of 7 sire families and two genotypes at the sex-linked dwarfism locus $(D w$ and $d w)$ were reared on deep litter under normal (around $15-20^{\circ} \mathrm{C}$ after 4 weeks) and hot temperature (around $25-30{ }^{\circ} \mathrm{C}$ ) from $0-18$ weeks of age. Body weights at 4, 8, 12 and 18 weeks of age, shank lengths at 12 weeks, plasma glucose and uric acid levels at 18 weeks were measured. Results are as follows :

1) A very highly significant difference between genotypes was obtained in plasma uric acid level at 18 weeks, dwarfs having almost the double values than normals. As expected body weight and shank length differences were very highly significant. A difference for plasma glucose was found significant at 5 p. 100 level only with pooled environments.

2) Plasma uric acid was found to be appreciably elevated in the hot temperature group (increase being relatively more in normals than in dwarfs). Hot temperature had a very highly significant depressent effect on 8 and 12 weeks body weight. The effect was observed to be less significant at 4 weeks while it was non-significant for 18 weeks body weight and for plasma glucose level.

3) Effect of sire family was found to be significant for all the traits measured. No trait showed any genotype $\times$ family interaction.

4) Very highly significant interaction between genotype at $\mathrm{Dw}$ locus and temperature treatment was observed for body weights at $8,12,18$ weeks and plasma uric acid level, these traits being less affected at high temperature for dwarfs.
\end{abstract}

Four week body weight and shank length were also found to show significant interaction whereas such effect was non-significant for plasma glucose level.

\section{1. - Introduction}

A considerable amount of research has been carried out on the dwarfing effect of the $d w$ gene after it was first described by HutT (1949) and Merat (1969). ARscotT \& BERNIER (1968) demonstrated that dwarf Leghorn had a better feed

(*) Permanent address : Dept of Animal Science, G.B. Pant University of Agriculture \& Technology, Pantnagar, India. 
efficiency and could lead, therefore, to cheaper egg production. Also improvement by selection can be obtained for sexual maturity, laying rate and egg size. Dwarfs are also known to have better resistance to heat (MATHER \& AHMAD, 1971 ; Merat, Bordas \& Lefebvre, 1974; Horst \& Petersen, 1978) and a tendency to lower mortality (BERNIER \& ARSCOTT, 1972). But, it appears that very little research has been conducted to study the performance of dwarf layers, particularly dwarf Leghorns, reared from the beginning under hot environmental conditions simulating the tropical climate.

In view of the above, a study on dwarf and normal White Leghorn, reared under normal and hot temperature, has been undertaken and is in progress (results up to growth stage are presented in this paper), which may answer the possibility of utilizing the dwarf gene in layer populations, especially in the context of tropical conditions.

\section{2. - Material and methods}

Dwarf and normal White Leghorn female chicks were obtained from heterozygous sires $D w d w$ mated with dwarf females in two hatches at an interval of two weeks, during the month of september 1980. The chicks were reared on deep litter from 0 to 18 weeks of age in two temperature groups, the first hatch under normal temperature (around $15-20^{\circ} \mathrm{C}$ ) without heating after 4 weeks of age, and the second under hot temperature (around 25 to $30^{\circ} \mathrm{C}$ ) with additional heating. Temperature fluctuations occurred for both groups due to imperfect insulation of the pens.

Data on diurnal temperature variations, body weights at 4, 8, 12 and 18 weeks of age, shank lengths at 12 weeks and plasma glucose and uric acid at 18 weeks were obtained from a total of 247 individuals, out of which half (122) were dwarfs. The two blood parameters were chosen as indicators of metabolic activity, and, for the second, of protein catabolism, in view of possible effects associated with the dwarfing gene.

Birds were distributed at random into the two temperature groups within each sire family, although the representation of each sire family and genotype could not be exactly equal due to the variations in the number of each genotype hatched under each sire family.

The plasma glucose and uric acid were measured immediately after the collections of blood samples (on the morning, birds being without food from $17 \mathrm{~h}$ the day before) at 18 weeks of age by a «Beckman Glucose Analyser » apparatus.

For each trait analysis of variance was done separately for the two environments and then for environments combined with genotype at the Dw locus as the controlled source of variation. Phenotypic correlation coefficients among different traits were also calculated within environment and genotype. The pooled estimates of correlation coefficients were done after testing the correlations for homogeneity. Covariance analysis on plasma uric acid was carried out, to test the effect of genotype after removing the effect of body weight. 


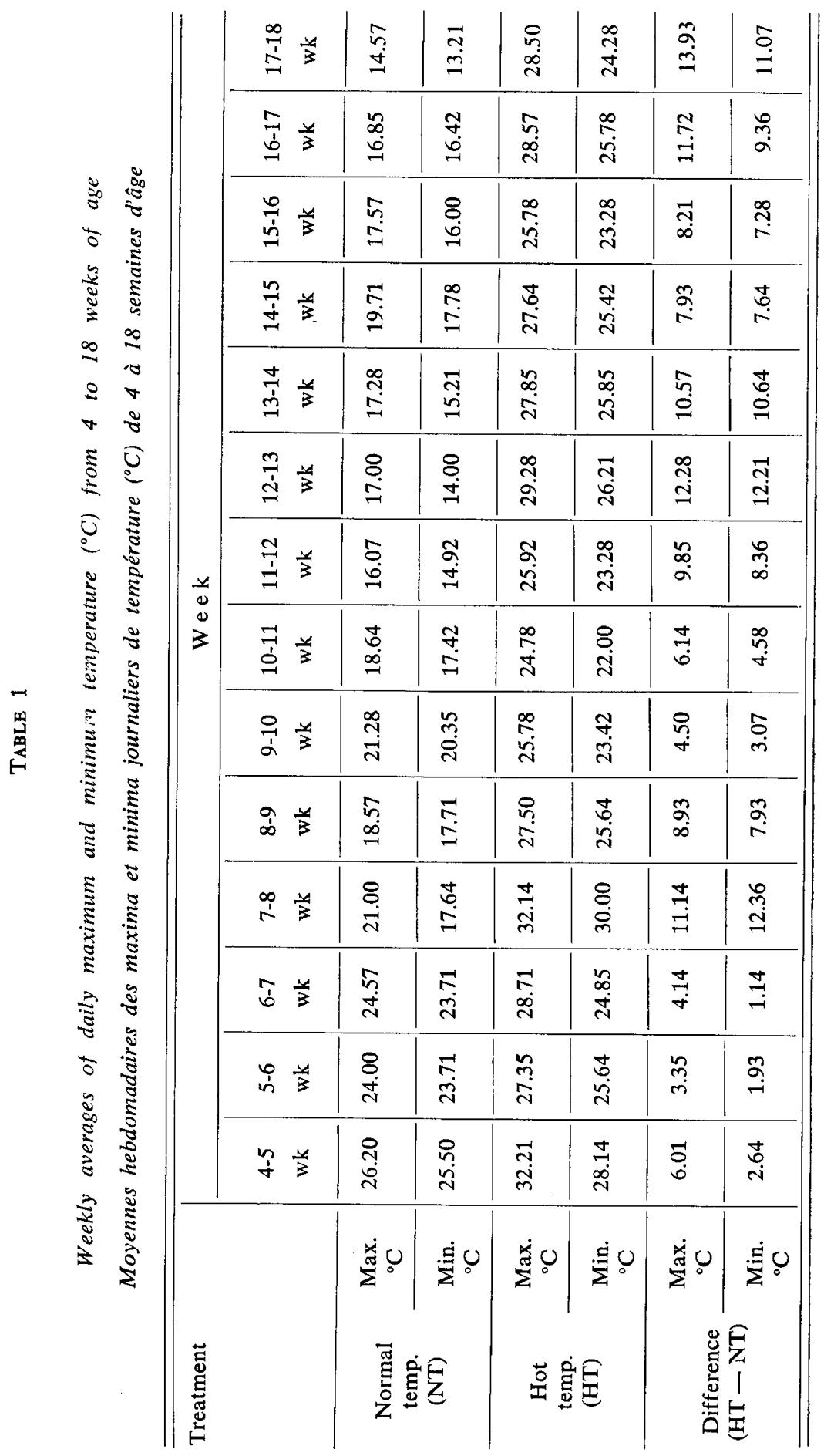


TABLE 2

Means, standard deviations and c.v. for body weights, shank length, glucose and uric acid for the two genotypes at Dw locus in the two environmental conditions

\begin{tabular}{|c|c|c|c|c|c|c|c|c|c|c|c|}
\hline \multirow{2}{*}{$\begin{array}{l}\text { Treat- } \\
\text { ment }\end{array}$} & \multirow{2}{*}{ Genotype } & \multirow{2}{*}{$\begin{array}{l}\text { Nb. of } \\
\text { indivi- } \\
\text { duals }\end{array}$} & \multicolumn{3}{|c|}{$\begin{array}{c}\text { Body wt. at } 4 \text { wks } \\
\text { (g) }\end{array}$} & \multicolumn{3}{|c|}{$\begin{array}{c}\text { Body wi. at } 8 \text { wks } \\
(\mathrm{g})\end{array}$} & \multicolumn{3}{|c|}{$\begin{array}{c}\text { Body wt. at } 12 \text { wks } \\
(\mathrm{g})\end{array}$} \\
\hline & & & Mean & S.D. & C.V. & Mean & S.D. & C.V. & Mean & S.D. & C.V. \\
\hline \multirow{3}{*}{$\begin{array}{l}\text { Normal } \\
\text { temp. } \\
\text { (I) }\end{array}$} & Dw & 65 & 171.6 & 29.9 & 17.4 & 543.2 & 70.0 & 12.9 & 986.9 & 87.5 & 8.9 \\
\hline & $d w$ & 72 & 131.2 & 23.6 & 18.0 & 365.8 & 54.4 & 14.9 & 611.0 & 73.7 & 12.1 \\
\hline & $\begin{array}{l}\mathrm{dw} / \mathrm{Dw} \\
\times 100\end{array}$ & & 76.5 & & & 67.3 & & & 61.9 & & \\
\hline \multirow{3}{*}{$\begin{array}{l}\text { Hot } \\
\text { temp. } \\
\text { (II) }\end{array}$} & Dw & 60 & 157.6 & 25.5 & 16.2 & 468.1 & 53.0 & 11.3 & 892.5 & 89.8 & 10.1 \\
\hline & $d w$ & 50 & 126.3 & 17.2 & 13.6 & 337.2 & 35.6 & 10.6 & 583.7 & 69.5 & 11.9 \\
\hline & $\begin{array}{l}\mathrm{dw} / \mathrm{Dw} \\
\times 100\end{array}$ & & 80.1 & & & 72.0 & & & 65.4 & & \\
\hline I & Total & 137 & 150.3 & 一 & 一 & 450.0 & 一 & 一 & 789.3 & 一 & 一 \\
\hline II & Total & 110 & 143.3 & 一 & 一 & 408.6 & - & 一 & 752.1 & - & - \\
\hline $\begin{array}{l}\text { Diffe- } \\
\text { rence } \\
\mathrm{I}-\mathbf{I I}\end{array}$ & & & 7.0 & & & 41.4 & & & 37.2 & & \\
\hline
\end{tabular}


Moyennes, écarts-types et coefficients de variation pour les poids corporels, la longueur des tarses, le glucose et l'acide urique pour les deux génotypes au locus $D w$ dans les deux environnements

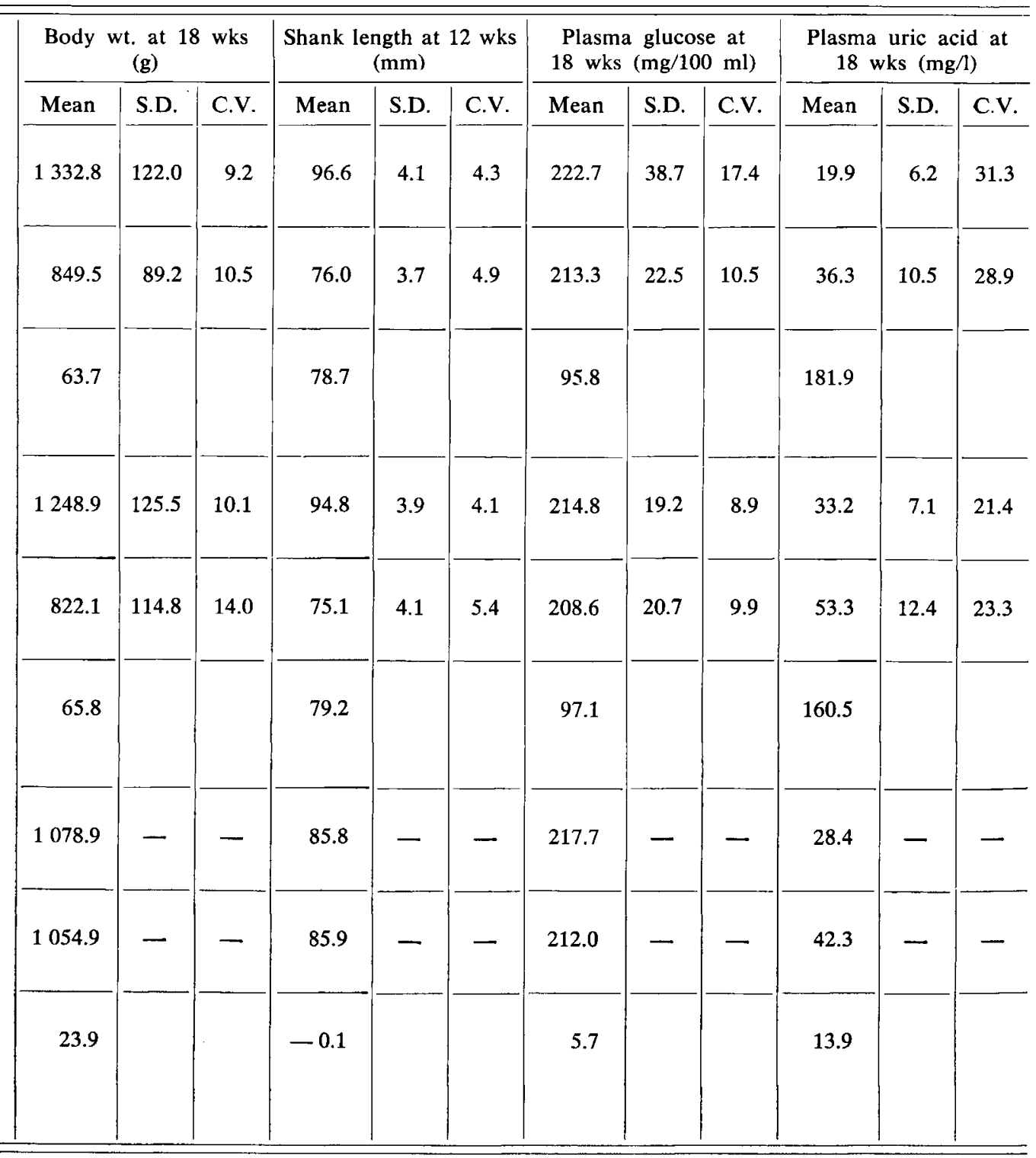




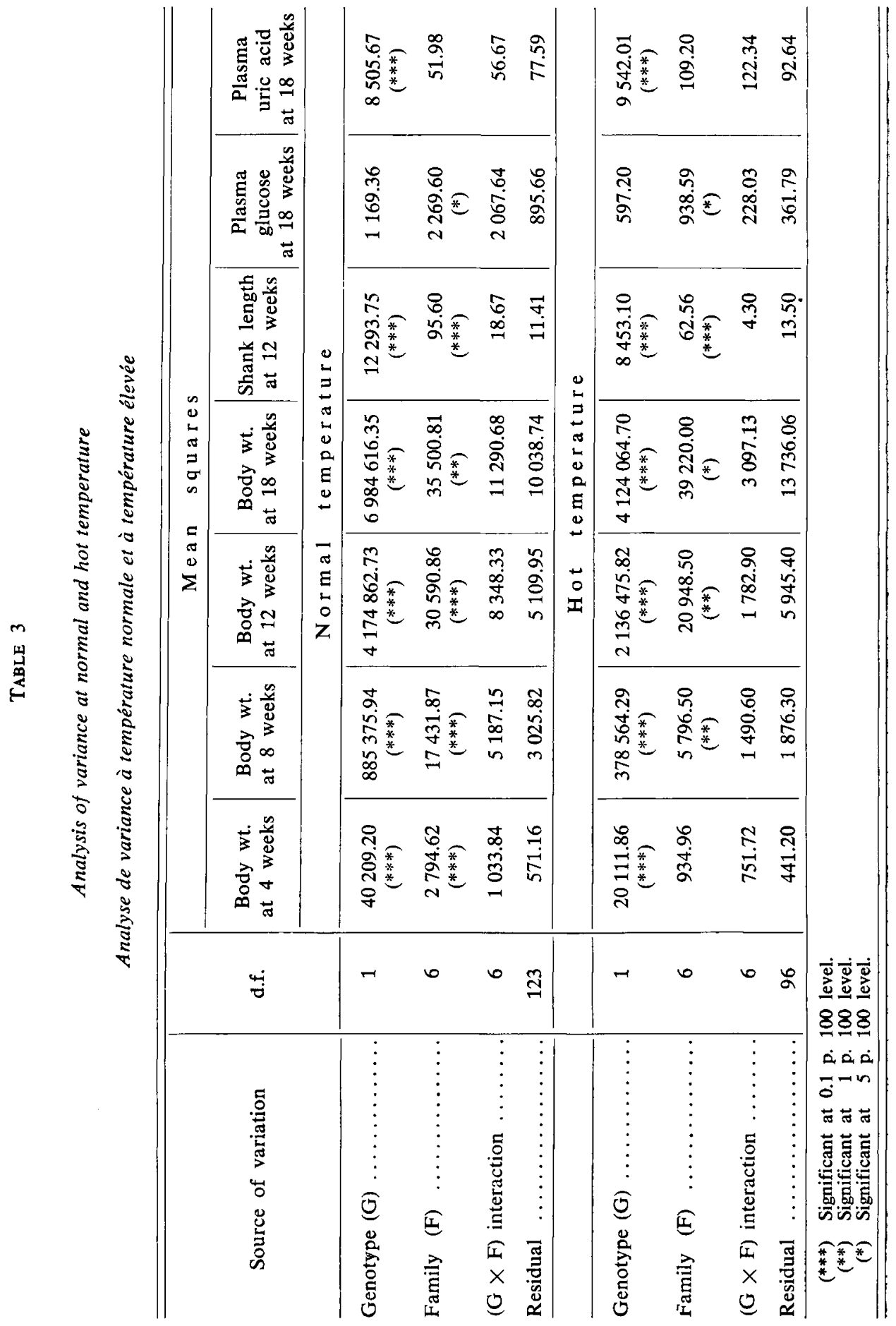




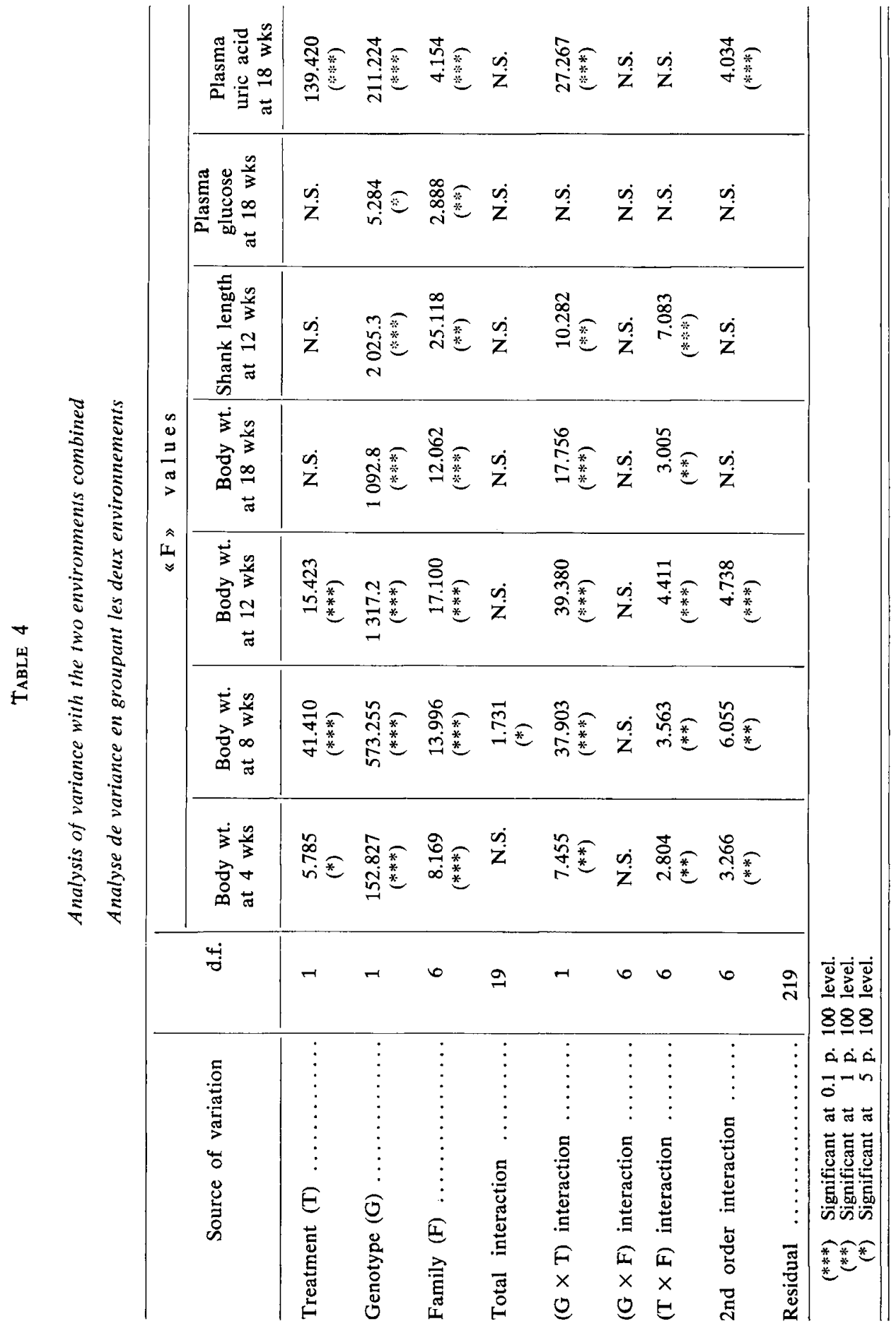


TABLE 6

Phenotypic correlations between different characters with genotype and environment combined Corrélations phénotypiques entre les différents caractères, génotypes et environnements groupés

\begin{tabular}{|c|c|c|c|c|c|c|}
\hline Characters & $\begin{array}{c}8 \text { week } \\
\text { body wt. }\end{array}$ & $\begin{array}{l}12 \text { week } \\
\text { body wt. }\end{array}$ & $\begin{array}{l}18 \text { week } \\
\text { body wt. }\end{array}$ & $\begin{array}{c}\text { Shank } \\
\text { length } \\
\text { at } \\
12 \text { weeks }\end{array}$ & $\begin{array}{c}\begin{array}{c}\text { Plasma } \\
\text { glucose } \\
\text { at }\end{array} \\
18 \text { weeks }\end{array}$ & $\begin{array}{c}\text { Plasma } \\
\text { uric acid } \\
\text { at } \\
18 \text { weeks }\end{array}$ \\
\hline 4 week body wt. .. & $\begin{array}{l}0.809 \\
(* * *)\end{array}$ & $\begin{array}{l}0.640 \\
(* * *)\end{array}$ & $\begin{array}{l}0.431 \\
(* * *)\end{array}$ & $\begin{array}{l}0.537 \\
(* * *)\end{array}$ & -0.071 & -0.069 \\
\hline 8 wrek body wt. . & & $\begin{array}{l}0.872 \\
(* * *)\end{array}$ & $\begin{array}{l}0.652 \\
(* * *)\end{array}$ & $\begin{array}{l}0.748 \\
(* * *)\end{array}$ & -0.050 & -0.132 \\
\hline 12 week body wt. ... & & & $\begin{array}{l}0.837 \\
(* * *)\end{array}$ & $\begin{array}{l}0.845 \\
(* * *)\end{array}$ & -0.006 & $\begin{array}{c}-0.140 \\
(*)\end{array}$ \\
\hline 18 week body wt. & & & & $\begin{array}{l}0.775 \\
(* * *)\end{array}$ & 0.080 & -0.202 \\
\hline Shank length at 12 weeks & & & & & -0.027 & -0.108 \\
\hline Plasma glucose at 18 weeks & & & & & & $\begin{array}{c}-0.140 \\
\left(^{*}\right)\end{array}$ \\
\hline
\end{tabular}

$(* * *)$ Significant at 0.1 p. 100 level.

(**) Significant at 1 p. 100 level.

(*) Significant at 5 p. 100 level.

TABLE 7

Covariance analysis for plasma uric acid correc'ed for regression on body weight (pooled on a within environment basis)

Analyse de covariance pour l'acide urique plasmatique corrigé pour sa régression sur le poids corporel (regroupé sur une base intra-environnement)

\begin{tabular}{|c|c|c|c|}
\hline Source of variation & Variance & d.f. & F \\
\hline $\begin{array}{l}\text { Between genotypes (deviation from re- } \\
\text { gression) } \ldots \ldots \ldots \ldots \ldots \ldots \ldots \ldots \ldots\end{array}$ & 751.30 & 1 & $9.13(* *)$ \\
\hline Difference between regression coefficients & 166.33 & 1 & 2.02 \\
\hline Residual & 82.32 & 238 & \\
\hline
\end{tabular}

$(* *)$ Significant at 1 p. 100 level. 


\section{3. - Results}

Table 1 gives weekly averages of daily maximum and minimum temperature in ${ }^{\circ} \mathrm{C}$ under normal and hot temperature on deep litter from 4th to 18 th week of growth. Table 2 presents the mean, standard deviation (S.D.) and coefficient of variation (C.V.) for the body weights, shank length, plasma glucose and uric acid under the two temperatures with genotypes separate and combined. Also presented in table 2 is the per cent of dwarf to normal genotypes $(\mathrm{dw} / \mathrm{Dw} \times 100)$ for the two treatments. Tables 3 and 4 give the analysis of variance for the characters with environments separate and combined respectively. Table 5 presents the phenotypic correlations of plasma glucose and uric acid with body weights and shank length under separate genotype and environment whereas table 6 gives all the correlations pooled for both genotypes and environments on a within-group basis. Table 7 shows the covariance analysis between genotypes for plasma uric acid with effect of body weight on plasma uric acid removed.

\section{4. - Discussion}

\section{Body weights}

As mentioned in table 1 maximum and minimum temperature of 30 " $\mathrm{C}$ and above under hot environment was achieved only during 7 th-8th week. Corresponding to this it is observed that maximum reduction of body weight of $41.37 \mathrm{gm}$ due to temperature was also achieved during this period. Although the maximum and minimum temperature at 4 weeks was also near $30^{\circ} \mathrm{C}$, it appears that its effect on body weight was carried over later and there was very little difference in body weight $(7.0 \mathrm{gm})$ between normal and hot temperature at the 4 week stage. From tables 1 and 2 it is also observed that although the difference in temperature hetween normal and hot group was $10^{\circ} \mathrm{C}$ or more during 7 th-8th weeks, 12th-13th weeks, 13th-14th weeks, 16th-17th weeks and 17th-18th weeks, the body weight difference between the normal and hot groups reduced after 8 weeks stage to the extent that at 18 weeks the difference was non-significant. Thus in this present experiment the difference of temperature of $10^{\circ} \mathrm{C}$ or above between normal and hot group had a bearing on body weight only when the maximum or minimum temperature in hot group was above $30^{\circ} \mathrm{C}$. But this effect may also be due to the stage of growth and age of the birds. From the percent values of dwarf to normals under normal and hot temperature group in table 2 it can be easily observed that dwarfs have relatively less reduction in body weight under hot temperature compared to normals. This effect was also maximum (dwarfs being 67.3 p. 100 of normals in the control group v 72.0 p. 100 in the hot group) at the 8 week stage when the maximum and minimum temperature in the hot temperature group was around $30^{\circ} \mathrm{C}$ or above. The relatively better growth of the dwarf genotype under hot temperature can be seen from table 4 where the effect due to genotype $\times$ treatment interaction is highly significant for body weights. 
The effect due to treatment $\times$ family interaction was also found to be highly significant for body weight and shank lengths indicating thereby that within genotype there exists familial differences for tolerance of heat. Merat et al. (1974) using two different environmental temperatures $\left(20^{\circ} \mathrm{C} \vee 28-34{ }^{\circ} \mathrm{C}\right)$ also observed a better resistance to heat in dwarf birds that decreased less their laying performances and food intake and increased less their water intake. MATTER \& AHMAD (1971) found a less increase in body temperature in dwarfs following abrupt change of environmental təmperature from 22 to $40^{\circ} \mathrm{C}$. Selvarajah (1974) suggests that dwarf hens will be at an advantage in hot climates. Horst \& PETERSEN (1978) tested dwarf and normal White Leghorns under moderate $\left(20^{\circ} \mathrm{C}\right)$ and high $\left(32^{\circ} \mathrm{C}\right)$ temperature and observed significant interaction favouring the lighter body weight types for egg production and body weight at the higher temperature. However, no special resistance to high temperature of dwarf chickens reared at $40^{\circ} \mathrm{C} v 22^{\circ} \mathrm{C}$ was found by Ahmad et al. (1971, 1974). Guillaume (1976) suggests that the better performance of dwarfs under hot temperature may be related to the size of the bird and to lower thyroid activity.

\section{Glucose}

From table 3 it can be observed that levels of plasma glucose in dwarfs and normals were not significantly different within each environment. However at both temperatures this parameter is slightly lower for $\mathrm{dw}$ birds and table 4 shows that when environments are combined the difference between genotypes is significant at 5 p. 100 level. This suggests a slightly different regulation mechanism of plasma glucose in dw and Dw genotypes in accordance with results of GuILlaume (1972). On the other hand, there exists a significant sire family effect on plasma glucose. The temperature apparently does not affect the plasma glucose level. WARD \& PeTERson (1973) also did not find a change in plasma glucose level in broilers exposed to 33-35 " $\mathrm{C}$ for 4 hours. However, the average plasma glucose level reported in the present study is somewhat lower than the value of $233 \mathrm{mg} / 100 \mathrm{ml}$ observed by TAPPER \& KARE (1960) in White Leghorn hens. This difference may be attributed to age, strain or environmental differences.

Phenotypic correlations between different characters under separate genotype and environment (table 5) were tested for heterogeneity and found to be non-significant. Pooled correlation estimates were found (table 6) to be non significant with all characters except plasma uric acid indicating that plasma glucose level was independent of body weights and shank length and slightly negatively associated with plasma uric acid level.

\section{Uric acid}

The mean values obtained (table 2) are in the range of values considered as normal : see for instance Bell \& FreEman (1971).

From table 2, 3 and 4 it can be observed that plasma uric acid level is highly significantly affected by genotype (almost double in dwarfs as compared to normals : $36.25 \mathrm{mg} \vee 19.90 \mathrm{mg} / \mathrm{l}$ ) and treatment, with a significant genotype $\times$ treatment interaction. The level increases with temperature in both dwarfs and normals, the 
proportional increase being more in normals than in dwarfs $(33.20 \mathrm{v} 53.30 \mathrm{mg} / \mathrm{l})$. WARD \& PETERson (1973) also obtained significantly higher plasma uric acid level in broilers exposed for 4 hours to $33-35^{\circ} \mathrm{C}$. The possible reason attributed to such higher level was cellular damage as a direct consequence of heat. If this explaination holds good it again leads to the conclusion that dwarfs sustain hot temperature better as concerns such cellular damage.

Phenotypic correlations of plasma uric acid with all other traits, with genotype and environment separate, were all non significant and low (table 5). But the pooled estimates (table 6) were found to be significantly negative at 5 p. 100 level with 8 week, 12 week body weight and plasma glucose and at 1 p. 100 level with 18 week body weight. The covariance analysis removing the effect of body weight on plasma uric acid shows that the effect of genotype on plasma uric acid remains highly significant, indicating a strong and specific effect of the dwarf gene, independent of its size reducing effect, on plasma uric acid.

Studies on uric acid clearance by the kidney tubules indicates (Bell \& Freeman, 1971) that as the plasma level of uric acid increases, the amount filtered continues to increase, until at a very high plasma level the ability of the tubules to secrete uric acid declines. Impaired renal clearance of uric acid of hereditary origin in chicken has also been reported by Austic \& COLE (1972) where the renal clearance of high uric acid strain was markedly less than that of the normal strain. It is also reported that when an organism cannot, by dietary means, obtain sufficient amounts of an essential amino acid, it catabolizes body protein, to obtain this amino acid. This process naturally leads to an increased excretion of nitrogen, in birds mostly as uric acid.

Scanning through the literature it appears that there is no report yet on the measure of either plasma uric acid or its clearance in dwarfs. However, Wood et al. (1971) demonstrated that protein metabolism of dwarf hens differed from that of normal siblings. Guillaume (1972) also demonstrated that the level of free amino acids is lower in dwarf birds. Guillaume \& Larbier (1974) and Guillaume (1975) also obtained an estimation of protein anabolism per $g$ of tissue higher in dwarf chicks, which was similar to the findings of BROwN et al. (1972). Since the dwarf chick has a smaller protein retention (GuILlaume, 1969) this higher anabolism (per unit body weight) is necessarily bound to a faster catabolism.

Thus the higher plasma uric acid level in dwarfs, reported in the present study, may be due to an hereditary impaired renal clearance associated with the $d w$ gene or to the result of higher protein catabolism as reported by GuILlaume (1975). Also the dwarfs may not be able to obtain, by dietary means, sufficient amount of some essential amino acids, resulting into higher protein catabolism, thereby higher plasma uric acid level. These various possibilities for higher uric acid level in plasma of dwarfs need to be verified.

Finally, it is of interest to observe that, when environments and genotypes at $\mathrm{dw}$ locus are pooled, there are significant sire family effects on plasma uric acid (table 4), which may allow some selection on this trait in dwarf stock. 


\title{
Acknowledgements
}

We thank Dr M. Larbier and Mr F.H. Ricard, Station de Recherches avicoles, 37380 Monnaie, for their useful criticisms concerning this manuscript.

\author{
Résumé \\ Effets de la température et du génotype sur la croissance \\ et le taux plasmatique de glucose \\ et d'acide urique de Poulettes Leghorn blanches naines et normales
}

Des Poussins femelles de race Leghorn blanche, issus de 7 familles de père, appartenant aux deux génotypes $D w$ ou $d w$ (taille normale ou naines) au locus $D w$ lié au sexe, ont été élevés sur litière, une moitié d'entre eux à température "normale» après 4 semaines $\left(15\right.$ à $20^{\circ} \mathrm{C}$ ), l'autre moitié à température élevée (environ 25 à $30^{\circ} \mathrm{C}$ ), de 0 à 18 semaines d'âge. Le poids corporel à $4,8,12$ et 18 semaines, la longueur des tarses à 12 semaines, et le taux plasmatique de glucose et d'acide urique à 18 semaines ont été mesurés. Les résultats sont les suivants :

1) Entre génotypes, une différence très hautement significative a été obtenue pour le taux d'acide urique plasmatique à 18 semaines, les poulettes naines ayant en moyenne des valeurs presque doubles des normales. Comme prévu, les différences pour les poids corporels et pour la longueur des tarses étaient hautement significatives. Une différence pour le glucose plasmatique n'apparaît significative que lorsqu'on réunit les deux environnements

2) L'acide urique plasmatique augmentait de façon appréciable dans le groupe maintenu à température élevée. La chaleur avait un effet dépressif très hautement significatif sur les poids corporels à 8 et 12 semaines. Cet effet était moins significatif à 4 semaines et devenait non significatif à 18 semaines.

3) L'effet de la famille de père a été trouvé significatif pour tous les caractères mesurés. Par contre, aucun caractère ne montre d'interaction génotype $\times$ famille.

4) Une interaction très hautement significative entre génotype au locus Dw et traitement a été observée pour le poids corporel à l'âge de 8,12 et 18 semaines, et le taux plasmatique d'acide urique, ces paramètres étant moins affectés à température élevée pour les naines. Le poids corporel à 4 semaines et la longueur des tarses présentaient aussi cette interaction, mais pas le taux plasmatique du glucose.

\section{References}

Ahmad M.M., Mather F.B.. Gleaves E.W., 1971. The effect of environmental temperature and dietary energy on dwarf and normal hens. Poult. Sci., 50, 1544 (abstr.).

Ahmad M.M., Mather F.B., Gleaves E.W., 1974. Effect of environmental temperature and dietary energy on dwarf and normal hens and normal roosters. Poult. Sci., 53, 927-935.

Arscott G.H., Bernier P.E., 1968. Effect of dietary protein on performance of dwarf White Leghorn layers. Poult. Sci., 47, 1652 (abstr.).

Austic R.E., Cole R.K., 1972. Impaired renal clearance of uric acid in chickens having hyperuricemia and articular gout. Amer. J. Physiol., 223, 525.

Bell D.J., Freeman B.M., 1971. Physiology and biochemistry of the domestic fowl. Academic Press, London. 
Bernier P.E., Arscott G.H., 1972. Fifteen years of observations on the dwarf gene in the domestic fowl. Ann. Génét. Sél. anim., 4, 183-215.

Brown R.G., Wood A.S., Reinhart B.S., Longworth D., 1972. Differences in amino acid activation found between dwarf and non-dwarf White Leghorn chickens. Poult. Sci., 51, 1067-1068.

Guillaume J., 1969. Conséquences de l'introduction du gène de nanisme dw sur l'utilisation alimentaire chez le Poussin femelle. Ann. Biol. anim. Biochim. Biophys., 9, 369-378.

Guillaume J., 1972. Quelques particularitếs rutritionnelles et physiologiques du Poussin nain dw. Ann. Génét. Sél. anim., 4, 233-250.

Guillaume J., Larbier M., 1974. C.R. Acad. Sci. Paris, 278, 1593, cited by Guillaume J., 1976, World's Poult. Sci. J., 32, 285-304.

Guillaume J., 1975. Recherches sur les caractéristiques nutritionnelles et métaboliques du Poussin nain $d w$. Thesis Doct. es Science, Univ. ef Tours, France.

Guillaume J., 1976. The dwarfing gene $d w$ : its effects on anatomy, physiology, nutrition, management. Its application in poultry industry. World's Poult. Sci. J., 32, 285-304.

Horst P., Petersen J., 1978. Der effekt des dwarf-gens auf das akklimatisationsvermögen von legehennen an hoile unwelttemperaturen. 16th World's Poultry Congress, I, 247-254.

HutT F.B., 1949. Genetics of the fowl. McGraw-Hill Book Company, New York.

Mather F.B., Ahmad M.M., 1971. Initial physiological responses of dwarf and normal laying hens to an abrupt increase in environmental temperature. Poult. Sci., 50, 1604 (abstr.).

Merat P., 1969. Etude d'un gène de nanisme lié au sexe chez la Poule. I. - Description sommaire et performances. Ann. Génét. Sél. anim., 1, 19-26.

Merat P., Bordas A., Lefebvre J., 1974. Effets associés aux gèries dw (nanisme) et Na («cou nu») chez la Poule sur la production d'œufs et la consommation alimentaire à deux températures. Ann. Gínćt. S.'l. anim., 6, 331-343.

Selvarajah T., 1974. Personnal communication, cited by Guillaume J., 1976, World's Poult. Sci. J., 32, 285-304.

Tapper D.N., Kare M.R., 1960. Proc. Soc. exp. Biol. Med., 92, 120-122. Cited by Bell D.J. and Freeamin B.M., 1971, Physiology and biochemistry of the domestic fowl, 2, 917, Academic Press, London and New 'York.

Ward M.A., Peterson R.A., 1973. The effect of heat exposure on plasma uric acid, lactate dehydrogenase, chloride, total prote.n and zinc of the broiler. Poult. Sci., 52, 1671-1673.

Wood A.S., Brown R.G., Summers J.D., Reinuart B.S., 1971. An aspect of protein biosynthetic activity by the dwarf ard non dwarf White Leghorn chicken. Poult. Sci., 50, 982-984. 